\title{
PENERAPAN PEMBELAJARAN TEMATIK DENGAN MODEL WEBBED UNTUK MENGUKUR KEMAMPUAN KOMUNIKASI MATEMATIS SISWA
}

\author{
Yunita Wildaniati \\ Universitas Muhammadiyah Metro, Jalan KH Dewantara 116 Kota Metro Lampung 34125 \\ Email: yunitawildaniati@yahoo.co.id
}

\begin{abstract}
Abstact: The purpose of this study is to improve the learning situation in the third grade of elementary school that the learning is not in accordance with the learning set by the Curriculum 2006 and does not pay attention to students' mathematical communication ability. Therefore, this study applies thematic learning with webbed model to measure students' mathematical communication ability. The type of research used is classroom action research, and implemented in one cycle. This classroom action research was conducted in MI Nurul Huda Sadar Sriwijaya Lampung Timur with the subject of third grade student research which amounted to 35 students. The results showed that classroom action research with the central theme "Rumahku" can measure students' mathematical communication ability.
\end{abstract}

Key words: thematic instructions, webbed model, mathematical communication

\begin{abstract}
Abstrak: Tujuan penelitian ini adalah untuk memperbaiki situasi pembelajaran di kelas III SD bahwa pembelajaran belum sesuai dengan pembelajaran yang telah ditetapkan oleh Kurikulum 2006 dan tidak memperhatikan kemampuan komunikasi matematis siswa. Oleh karena itu, penelitian ini menerapkan pembelajaran tematik dengan model webbed untuk mengukur kemampuan komunikasi matematis siswa. Jenis penelitian yang digunakan adalah penelitian tindakan kelas, dan dilaksanakan dalam satu siklus. Penelitian tindakan kelas ini dilakukan di MI Nurul Huda Sadar Sriwijaya Lampung Timur dengan subjek penelitian siswa kelas III yang berjumlah 35 siswa. Hasil penelitian menunjukkan bahwa penelitian tindakan kelas dengan tema sentral "Rumahku" dapat mengukur kemampuan komunikasi matematis siswa.
\end{abstract}

Kata kunci: pembelajaran tematik, model webbed, kemampuan komunikasi matematik

Siswa kelas I, II, dan III SD berada pada rentangan usia dini. Pada umumnya tingkat perkembangan masih memandang dan mempelajari segala peristiwa yang terjadi di sekitarnya atau yang dialaminya sebagai suatu kesatuan yang utuh (holistik) serta mampu memahami hubungan antara konsep secara sederhana. Proses pembelajaran masih bergantung kepada objek-objek konkret dan pengalaman yang dialami secara langsung. Pembelajaran di sekolah, khususnya sekolah dasar (SD), terdapat sejumlah muatan yang harus dipelajari siswa, salah satunya adalah Matematika. Badan Standar Nasional Pendidikan (2006) menyatakan terdapat kemampuan dasar SD sampai dengan SMA yang perlu diupayakan peningkatannya yaitu komunikasi matematis sebagaimana kemampuan dasar lainnya, seperti kemampuan bernalar, kemampuan pemahaman matematis, kemampuan pemecahan masalah, kemampuan komunikasi matematis dan koneksi, serta kemampuan representasi matematis.

Studi pendahuluan, peneliti melakukan pengamatan dan wawancara dengan guru dan siswa MI Nurul Huda Sadar Sriwijaya Lampung Timur tentang proses pembelajaran di kelas bawah. Hasil pengamatan dan wawancara tersebut terdapat beberapa permasalahan yang terjadi, diantaranya adalah: (1) siswa jarang bertanya karena belum mampu membuat pertanyaan tentang materi yang 
dipelajari (siswa tidak dilatih bertanya); (2) siswa belum mampu memberikan tanggapan karena belum mampu menjelaskan ide-ide matematika dengan baik (siswa tidak dilatih bertanya); (3) ada siswa yang mampu menyelesaikan soal matematika tetapi tidak mengerti apa yang dikerjakannya, dan kurang memahami apa yang dikerjakannya (tidak meaningfull); (4) masih banyak siswa yang mengalami kesulitan dalam memahami soal cerita; (5) banyak siswa yang mengalami kesulitan dalam mengerjakan soal yang sedikit berbeda dengan contoh soal yang telah diberikan; (6) kegiatan pembelajaran untuk setiap mata pelajaran dilakukan secara terpisah sehingga membuat siswa mengalami kesulitan dalam menerima konsep materi dari beberapa mata pelajaran yang berbeda setiap harinya; dan (7) guru tidak pernah memperhatikan kemampuan komunikasi matematis siswanya.

Berdasarkan hasil pengamatan, terdapat fakta yang dijumpai yaitu dalam pelaksanaan pembelajaran matematika sehari-hari, jarang sekali siswa diminta untuk mengomunikasikan ideidenya. Hal ini dibuktikan banyak siswa yang tidak mampu menerapkan konsep matematika terhadap disiplin ilmu lain maupun dalam memecahkan masalah matematika dalam kehidupan sehariharinya. Selain itu, dari hasil pengamatan dan wawancara dengan guru MI tersebut diperoleh bahwa siswanya kurang mampu menyelesaikan soal matematika yang berupa soal cerita yang berkaitan dengan kehidupan sehari-hari.

Permasalahan berikutnya, kegiatan pembelajaran yang dilakukan secara terpisah membuat siswa mengalami kesulitan dalam menerima konsep. Hal tersebut, diakui guru bahwa siswa mengalami kesulitan dalam menerima konsep materi dari berbagai mata pelajaran setiap harinya. Sesuai dengan tahapan perkembangan anak yang masih melihat segala sesuatu sebagai suatu keutuhan (berpikir holistik), pembelajaran yang menyajikan mata pelajaran secara terpisah akan menyebabkan kurang mengembangkan anak untuk berpikir holistik. Demikian juga untuk pelaksanaan kegiatan pembelajaran matematika yang terpisah kurang dapat mengembangkan kemampuan koneksi matematis para siswanya. Karena dengan pembelajaran matematika yang terpisah akan membuat kesulitan bagi anak dalam menemukan keterkaitan- keterkaitan antar mata pelajaran maupun dengan kehidupan sehari-harinya. Hal ini dapat dibuktikan dalam beberapa hal, diantaranya: siswa lebih mudah mengerjakan soal matematika yang berbentuk isian langsung daripada mengerjakan soal cerita. Di dalam soal cerita, selain siswa harus mampu menguasai konsep matematika juga siswa dituntut untuk memahami bahasanya. Di sinilah letak kemampuan komunikasi matematis diperlukan.

Selain itu, dengan pelaksanaan pembelajaran yang terpisah, muncul permasalahan pada kelas rendah $(1,2$, dan 3$)$ antara lain adalah tingginya angka mengulang kelas. Angka mengulang kelas siswa kelas I SD jauh lebih tinggi dibandingkan dengan kelas yang lain. Data tahun 2000 yang disebutkan Departemen Pendidikan dan Kebudayaan (2004) memperlihatkan bahwa angka mengulang kelas pada kelas satu sebesar $11,46 \%$ sementara pada kelas dua $7,44 \%$, kelas tiga $6,23 \%$, kelas empat $4,71 \%$, kelas lima 3,27\%, dan kelas enam $0,41 \%$. Salah satu upaya untuk mengatasi permasalahan di atas, perlu diterapkan sistem pembelajaran yang dapat memadukan antara satu mata pelajaran dengan mata pelajaran lainnya. Sebagaimana disebutkan oleh Sukayati (2004), bagi guru sekolah dasar kelas rendah yang siswanya masih berperilaku dan berpikir konkret, pembelajaran sebaiknya dirancang secara terpadu dengan menggunakan tema sebagai pemersatu kegiatan pembelajaran. Dengan cara ini maka pembelajaran untuk siswa kelas rendah akan menjadi lebih bermakna, lebih utuh dan sangat kontekstual dengan dunia anak-anak.

Untuk mengatasi hal tersebut, diterapkan dengan pembelajaran model webbed. Pembelajaran dengan model webbed siswa tidak terpisah dengan kehidupan nyata dan tidak gagap dalam menghadapi perkembangan zaman. Rumusan masalah penelitian adalah apakah penerapan pembelajaran tematik dengan model webbed dapat untuk mengukur kemampuan komunikasi matematis siswa kelas III SD di MI Nurul Huda Sadar Sriwijaya Lampung Timur?

\section{METODE}

Jenis penelitian yang digunakan adalah penelitian tindakan kelas (PTK). McKennan menyatakan bahwa penelitian tindakan kelas dapat terdiri dari satu, dua, tiga atau empat siklus dengan 
setiap siklus di akhiri dengan refleksi (Kartowagira, 2005). Dipilihnya jenis PTK dalam penelitian ini adalah karena tujuan penelitian ini sesuai dengan karakteristik PTK, yaitu ingin memperbaiki kualitas proses pembelajaran perkalian bilangan dengan penerapan strategi interaksi. Penelitian ini berangkat dari permasalahan yang terjadi pada pembelajaran perkalian bilangan, dalam melaksanakan penelitian peneliti berkolaborasi dengan guru kelas baik pada saat pelaksanaan tindakan maupun melakukan refleksi setiap akhir tindakan. PTK sangat memperhatikan proses pembelajaran disamping hasil belajarnya, hal ini sesuai dengan proses penelitian dengan pendekatan kualitatif yang akan dilaksanakan.

Model PTK yang digunakan adalah model Lorenz Bachman, penelitian dilaksanakan dalam tiga tahap penelitian, yaitu: perencanaan tindakan, pelaksanaan, dan observasi tindakan, dan refleksi yang berlangsung dalam siklus atau kegiatan berulang. Siklus berikutnya dilakukan apabila siklus yang baru dilaksanakan dianggap tidak berhasil sesuai kriteria keberhasilan yang ditetapkan. Perencanaan siklus berikutnya memperhatikan hasil refleksi siklus sebelumnya. Penelitian ini dilakukan di MI Nurul Huda Sadar Sriwijaya Lampung Timur. Penelitian ini dilakukan dalam satu siklus dengan enam kali pertemuan. Prosedur pengumpulan data dalam penelitian ini berupa validasi perangkat penelitian, pengamatan (observasi) aktivitas siswa dan aktivitas guru, wawancara, dan tes hasil belajar siswa. Perangkat penelitian yang digunakan adalah lembar validasi, lembar observasi, format wawancara, instrumen tes, rencana pembelajaran, dan lembar kerja siswa.

\section{HASIL}

Pembelajaran tematik model webbed dapat mengukur kemampuan komunikasi matematis siswa kelas III MI Nurul Huda Sadar Sriwijaya Lampung Timur. Hal ini berdasarkan kriteria keberhasilan penelitian yang yang telah ditetapkan yaitu ditentukan oleh hasil belajar siswa dan proses pembelajaran. Indikator hasil belajar siswa ditentukan oleh tuntas belajar siswa secara klasikal yaitu sekurang-kurangnya $85 \%$ dari keseluruhan siswa peserta pembelajaran tematik model webbed memperoleh nilai $\geq 65$ dan keberhasilan kemampuan komunikasi matematis siswa. Sedangkan indikator proses pembelajaran ditentukan oleh hasil observasi aktivitas guru dan aktivitas siswa. Hasil skor kemampuan komunikasi matematis mencapai skor 56,85 dimana skor tersebut berada pada interval skor $50 \leq \mathrm{T}_{1} \leq 60$. Sehingga kemampuan komunikasi matematis siswa berada pada kategori berhasil dan berdasarkan hasil tes belajar siswa telah mencapai ketuntasan belajar secara kelasikal, yaitu $100 \%$ siswa telah mencapai skor hasil belajar 65 atau lebih. Selain itu prosentase rata-rata hasil observasi aktivitas guru adalah 95,8\% dan prosentase hasil observasi aktivitas siswa diperoleh $93,7 \%$. Berdasarkan analisis hasil kegiatan observasi yaitu observasi aktivitas guru dan aktivitas siswa telah berjalan dengan sangat baik. Sehingga disimpulkan bahwa pembelajaran tematik model webbed dapat mengukur kemampuan komunikasi matematis siswa kelas III MI Nurul Huda Sadar Sriwijaya lampuung Timur.

\section{Penerapan Pembelajaran Tematik Model Webbed}

PTK dalam penelitian ini terdiri dari satu siklus dengan enam pertemuan. Penelitian ini tidak dilanjutkan ke siklus berikutnya karena pada proses refleksi dilakukan sudah memenuhi kriteria keberhasilan penelitian yang telah ditetapkan sehingga penelitian dihentikan. Langkah-langkah yang dilakukan dalam menerapkan pembelajaran tematik model webbed adalah: (1) guru membagi siswa dalam beberapa kelompok belajar dengan latar belakang heterogen; (2) guru menyampaikan tema yang akan digunakan dalam pembelajaran; (3) guru menyampaikan materi dan tujuan pembelajaran yang akan dicapai; (4) guru menyampaikan kegiatan pembelajaran yang akan dilakukan siswa; (5) guru memberikan kegiatan-kegiatan yang bertujuan untuk mengukur kemampuan komunikasi matematis siswa, kegiatan-kegiatan tersebut juga diharapkan dapat membantu siswa memahami konsep materi yang dipelajari dan membuat siswa merasa senang dalam belajar. Kegiatan yang dilakukan dengan memperhatikan Lembar Kerja Siswa (LKS) yang telah dibagikan; (6) guru memberi bimbingan pada setiap kelompok yang mengalami kesulitan; dan (7) guru dan siswa bersama-sama membuat kesimpulan materi yang telah dipelajari. 
Langkah-langkah tersebut dilakukan dalam enam kali pertemuan. Pada pertemuan pertama; guru membagi siswa dalam kelompok belajar yang beranggotakan lima orang dengan latar belakang akademik yang heterogen, hal ini dilakukan agar yang memiliki kemampuan tinggi dapat membantu yang memiliki kemampuan rendah dan sedang. Anggota kelompok belajar tersebut tetap mulai pertenuan pertama sampai keenam. Pada pertemuan pertama materi yang diajarkan adalah bangun datar dan bercerita, dalam pembelajaran guru memberikan kegiatan-kegiatan yang dapat membantu siswa memahami konsep bangun datar dan bercerita selain itu bertujuan untuk mengukur kemampuan komunikasi matematis siswa yang telah ditetapkan. Pada proses pembelajaran ini diketahui bahwa siswa salah konsep tentang letak sisi dengan letak titik sudut, untuk mengatasi hal tersebut guru mendatangi setiap kelompok untuk mengkonfirmasi kembali tentang letak sisi dan titik sudut dengan menggunakan alat peraga karton tebal.

Pada pertemuan kedua, materi yang diberikan adalah membuat rumah-rumahan, bangun datar, membaca puisi. Siswa secara berkelompok membuat rumah-rumahan dari berbagai bangun datar yang telah disediakan guru, dengan membuat rumah-rumahan tersebut siswa dapat mengidentifikasi berbagai bangun datar beserta sifat-sifatnya. Selain itu siswa dapat membuat gambar berdasarkan imajinasinya. Setelah selesai dengan rumahrumahan siswa membaca puisi yang berjudul "Rumahku". Pada pertemuan ketiga, materi yang diberikan adalah bangun datar, sudut, dan membuat gambar. Siswa mengidentifikasi bangun datar yang membentuk rumah-rumahannya, pada proses ini siswa dapat menentukan sudut pada benda dan bangun datar dengan menggunakan alat peraga kertas karton. Selain itu siswa juga membuat gambar-gambar dari berbagai bangun datar yang telah siswa ketahui sebelumnya, dimana mereka membuat gambar-gambar tersebut berdasarkan imajinasinya sendiri.

Pertemuan keempat, materi yang diberikan adalah denah rumah, sudut, dan membuat cerita. Denah rumah yang diberikan adalah denah rumah sederhana, dengan siswa menyebutkan nama-nama jalan yang terdapat pada denah tersebut membantu siswa untuk menentukan sudut dan siswa dapat menjelaskan konsep sudut sebagai daerah yang dibatasi oleh dua sinar atau garis yang bertemu di satu titik. Denah tersebut membuat siswa dapat membandingkan dan mengurutkan besar sudut, selain itu membuat siswa dapat menyebutkan jenisjenis sudut (sudut lancip, sudut siku-siku, sudut lancip). Denah sederhana tersebut juga membantu siswa dalam membuat karangan sendiri. Kendala yang ditemui pada pertemuan adalah saat siswa tidak dapat menggunakan busur derajat untuk mengukur sudut yang terbentuk pada denah, sehingga guru mendatangi setiap kelompok untuk mengajarkan cara mengukur sudut dengan menggunakan busur derajat. Selain itu guru memberi solusi siswa untuk menentukan apakah jenis sudut yang terbentuk hanya dengan memperhatikan bentuk sudutnya dan berpedoman pada bentuk sudut siku-siku. Sehingga siswa dapat menentukan dengan mudah jenis sudut yang terbentuk tanpa harus mengukur dengan busur derajat.

Pertemuan kelima, materi yang diberikan adalah gambar berseri dan denah rumah. Pada gambar berseri tersebut terdapat kegiatan-kegiatan yang dilakukan dan siswa akan melakukan kegiatan seperti digambar berseri dengan menggunakan sedotan dan perekat yang telah disediakan. Namun sebelum siswa melakukannya, siswa diminta membaca gambar berseri dan menceritakan kembali apa yang ada di gambar berseri tersebut. Kegiatan-kegiatan yang terdapat digambar berseri membuat siswa lebih memahami tentang sudut dan jenis-jenis sudut beserta ukurannya. Selain itu membantu siswa membandingkan antara segitiga siku-siku, segitiga sama kaki, dan segitiga sama sisi. Sedangkan denah rumah membantu siswa dalam membaca denah dan lebih memahami tentang konsep sudut.

Pertemuan keenam, materi yang diberikan adalah jam (weker dan dinding) dan denah rumah. Jam tersebut digunakan untuk membantu siswa dalam memahami konsep sudut sebagai jarak putar. Sedangkan denah rumah yang diberikan membantu siswa dalam menentukan arah mata angin sehingga siswa dapat menerapkan konsep sudut sebagai jarak putar dengan pengetahuan yang dimiliki siswa tentang arah mata angin. 


\section{Kemampuan Model Webbed Untuk Mengukur Komunikasi Matematis Siswa}

Kemampuan komunikasi matematis siswa yang dimaksud dalam penelitian ini adalah kemampuan siswa dalam mengekspresikan ide-ide matematis diantaranya adalah: (1) mengidentifikasi sifat-sifat bangun datar sederhana; (2) menentukan sudut pada benda atau bangun datar; (3) menerapkan konsep sudut sebagai jarak putar; (4) membuat gambar-gambar imajinatif; (5) membaca denah sederhana; dan (6) membuat cerita berdasarkan pengalaman sendiri atau dengan bantuan gambar. Tabel 1 menampilkan kemampuan komunikasi matematis siswa sebelum dan sesudah diterapkan pembelajaran tematik model webbed.

Mengidentifikasi sifat-sifat bangun datar sederhana disini maksudnya siswa dapat menyebutkan sifat-sifat bangun datar sederhana (persegi, persegi panjang, segitiga) dengan benar. Menentukan sudut pada benda atau bangun datar di sini berarti siswa dapat menentukan sudut pada atau bangun datar dengan benar. Menerapkan konsep sudut sebagai jarak putar yang dimaksud adalah dengan kegiatan-kegiatan yang diberikan dan dengan pengetahuannya tentang arah mata angin siswa dapat menerapkan konsep sudut sebagai jarak putar. Membuat gambar-gambar imajinatif yang dimaksud adalah siswa dapat membuat gambar sesuai imajinasi mereka sendiri tanpa harus takur berbeda dengan yang lainnya. Membaca denah yang dimaksud disini adalah dengan denah yang diberikan siswa dapat membaca denah sederhana dengan benar. Sedangkan maksud membuat cerita berdasarkan pengalaman atau dengan bantuan gambar adalah dengan pengalaman yang dimiliki dan bantuanm gambar yang ada siswa dapat membuat cerita.

Berdasarkan kriteria keberhasilan pembelajaran tematik dengan model webbed yang telah ditetapkan yaitu ditentukan oleh keberhasilan proses pembelajaran dan hasil tes siswa, dimana indikator proses pembelajaran ditentukan oleh hasil observasi aktivitas guru dan siswa dalam pembelajaran sedangkan indikator hasil tes siswa ditentukan oleh keberhasilan kemampuan komunikasi matematis siswa dan kriteria ketuntasan belajar. Setelah pembelajaran dilaksanakan diperoleh bahwa prosentase skor rata-rata aktivitas guru adalah $95,8 \%$ dan prosentase skor rata-rata siswa adalah 93,7\%. Berdasarkan analisis hasil kegiatan observasi aktivitas guru dan siswa telah berjalan dengan sangat baik. Hasil skor kemampuan komunikasi matematis siswa adalah 56,85 , dimana skor tersebut berada pada interval skor $50 \leq \mathrm{T}_{1} \leq 60$. Sehingga kemampuan komunikasi matematis siswa berada pada kategori berhasil dan berdasarkan hasil tes belajar siswa telah mencapai ketuntasan belajar secara klasikal, yaitu 100\% siswa telah mencapai skor 65 atau lebih. Sehingga disimpulkan bahwa pembelajaran tematik model webbed dapat mengukur kemampuan komunikasi matematis siswa.

\section{PEMBAHASAN}

Permasalahan tersebut terjadi sesuai dengan pendapat Cai, dkk., (1996) yang menyatakan bahwa sebagai akibat dari sangat jarangnya siswa dituntut untuk menyediakan penjelasan dalam pelajaran matematika, sehingga sangat asing bagi mereka untuk berbicara tentang matematika. Pugalee (2001) menyatakan dalam pembelajaran matematika siswa perlu dibiasakan untuk memberikan argumen atas setiap jawabannya serta memberikan tanggapan atas jawaban yang diberikan orang lain, sehingga apa yang sedang dipelajari menjadi lebih bermakna bagi siswa. Hal ini berarti bahwa dalam pembelajaran harus dapat memberikan waktu bagi siswa untuk berdiskusi dalam menjawab, menanggapi pernyataan, dan pertanyaan orang lain dengan menggunakan argumentasi yang benar dan jelas.

Model webbed adalah salah satu model pembelajaran terpadu yang menggunakan pendekatan tematik (Fogarty, 1991). Pendekatan tematik dapat dikatakan sebagai suatu pendekatan belajar mengajar yang melibatkan beberapa mata pelajaran untuk memberikan pengalaman bermakna, karena dalam pembelajaran tematik anak akan memahami konsep-konsep yang mereka pelajari melalui pengamatan langsung dan menghubungkannya dengan konsep lain yang mereka pahami (koneksi). Pendekatan ini pengembangannya dimulai dengan menentukan tema tertentu sebagai dasar pembelajaran dalam berbagai disiplin mata pelajaran, sehingga akan memberikan pengalaman yang bermakna, karena dalam model webbed lebih menekankan keterlibatan anak dalam belajar, membuat anak terlibat secara aktif dalam proses pembelajaran dan pemberdayaan dalam memecahkan masalah, tumbuhnya kreativitas sesuai kebutuhan siswa, 
Tabel 1 Kemampuan Komunikasi Matematis Siswa Sebelum dan Sesudah Pembelajaran Tematik Model Webbed



2. Menentukan sudut pada benda atau bangun datar

Sebagian besar siswa tidak dapat menentukan sudut pada benda atau bangun datar, tetapi siswa hanya mengetahui banyaknya sudut yang dimiliki benda atau bangun datar dengan cara menghafal.

3. Menerapkan konsep sudut sebagai jarak putar

4. Membuat gambar-gambar imajinatif

5. Membaca denah sederhana

6. Membuat cerita berdasarkan pengalaman atau dengan bantuan gambar
Sebagian besar siswa tidak mengetahui bahwa sudut dapat dibentuk dengan menggunakan jarum jam. Selain itu sebagian besar siswa tidak mengetahui bahwa arah mata angin dan sudut sangat berkaitan. Sehingga tidak dapat menerapkan konsep sudut sebagai jarak putar dengan benar.

Sebagian besar siswa tidak dapat membuat gambar sesuai imajinasinya sendiri karena takut salah apabila berbeda dengan teman-temannya.

Hanya ada beberapa siswa yang dapat membaca denah sederhana dengan benar karena guru tidak pernah mengajarkan cara membaca denah.

Sebagian besar siswa belum terbiasa membuat cerita berdasarkan pengalaman sendiri atau dengan bantuan gambar karena guru tidak pernah membiasakan siswa untuk melakukannya.

\section{Sesudah Pembelajaran Tematik} Model Webbed

Semua siswa dapat mengidentifikasi sifat-sifat bangun datar sederhana dengan benar tanpa harus menghafal, selain itu siswa dapat menentukan letak posisinya(bermakna).

Berdasarkan kegiatan-kegiatan yang telah diberikan siswa dapat menentukan sudut pada benda atau bangun datar dengan benar, sehingga siswa dapat menentukan berapa banyak sudut yang dimiliki benda atau bangun datar tersebut tanpa harus menghafal.

Melalui kegiatan yang telah diberikan semua siswa dapat membuat sudut dengan menggunakan jarum jam. Selain itu semua siswa dapat menerapkan konsep sudut dengan konsep arah mata angin yang telah mereka ketahui. Sehingga dapat menerapkan konsep sudut sebagai jarak putar dengan benar.

Dengan kegiatan-kegiatan yang telah diberikan semua siswa dapat membuat gambar-gambar sesuai imajinasi mereka sendiri tanpa takut berbeda dengan yang lainnya.

Berdasarkan kegiatan yang telah diberikan semua siswa dapat membaca denah seerhana benar.

Berdasarkan kegiatan-kegiatan yang telah diberikan semua siswa dapat membuat cerita berdasarkan pengalaman sendiri atau dengan bantuan gambar tanpa takut berbeda dari yang lain.

\section{Kesimpulan}

Siswa sudah mampu mengekspresikan ide-ide matematisnya. Sehingga kemampuan komunikasi matematis siswa sudah dapat diukur dengan pembelajaran tematik model webbed. 
anak akan memahami konsep-konsep yang mereka pelajari melalui pengamatan langsung dan menghubungkannya dengan konsep lain yang mereka pahami.

Sehingga penguasaan konsep mereka akan menjadi lebih baik. Tema atau topik bisa ditetapkan dengan bernegosiasi antara guru dan siswa, tetapi dapat pula dengan cara diskusi antara guru dan peneliti. Yang lebih penting tema ditentukan berdasarkan analisis kebutuhan siswa. Terdapat alasan yang mendasar dalam pemilihan model webbed ini, karena model tersebut tidak sulit dilaksanakan sepenuhnya dan tidak membutuhkan ketrampilan yang sangat tinggi bagi guru untuk melaksanakannya. Hal ini sejalan dengan pendapat Setiaty, dkk., (2014) bahwa kelebihan pembelajaran terpadu model webbed ialah pertama ada kekuatan motivasi yang berasal dari proses penentuan tema yang diminati oleh siswa, kedua model jaring Webbed relatif mudah dilaksanakan oleh para guru, termasuk guru pemula.

Komunikasi matematis merupakan salah satu jantung dalam pembelajaran, sehingga perlu menumbuhkembangkan dalam aktivitas pembelajaran matematika. Umar (2012) menyatakan ada dua alasan penting mengapa pembelajaran matematika terfokus pada pengkomunikasian. Pertama, matematika pada dasarnya adalah suatu bahasa. Kedua, matematika dan belajar matematis dalam bathinnya merupakan aktivitas sosial.

\section{KESIMPULAN DAN SARAN}

\section{Kesimpulan}

Langkah-langkah penerapan pembelajaran tematik model webbed yang dapat mengukur kemampuan komunikasi matematis siswa kelas III MI Nurul Huda Sadar Sriwijaya Lampung Timur yaitu: (1) guru membagi siswa dalam beberapa kelompok belajar dengan latar belakang heterogen; (2) guru menyampaikan tema yang akan digunakan dalam pembelajaran; (3) guru menyampaikan materi dan tujuan pembelajaran yang akan dicapai; (4) guru menyampaikan kegiatan pembelajaran yang akan dilakukan siswa; (5) guru memberikan kegiatan-kegiatan yang bertujuan untuk mengukur kemampuan komunikasi matematis siswa, kegiatan-kegiatan tersebut juga diharapkan dapat membantu siswa memahami konsep materi yang dipelajari dan membuat siswa merasa senang dalam belajar. Kegiatan yang dilakukan dengan memperhatikan LKS yang telah dibagikan; (6) guru memberi bimbingan pada setiap kelompok yang mengalami kesulitan; dan (7) guru dan siswa bersama-sama membuat kesimpulan materi yang telah dipelajari. Pembelajaran tematik model webbed dapat mengukur kemampuan komunikasi matematis siswa dan dapat membantu siswa memahami konsep materi dan membuat siswa merasa senang dalam belajar.

\section{Saran}

Pembelajaran tematik dengan model webbed dapat membantu untuk mengukur kemampuan komunikasi matematis siswa. Untuk itu guru disarankan untuk mencoba menerapkan pembelajaran tematik dengan model webbed dalam pembelajarannya. Efek samping pembelajaran tematik dengan model webbed membantu siswa memahami konsep dan membuat siswa merasa senang dalam belajar. Untuk itu guru disarankan untuk mencoba menerapkan pembelajaran tematik dengan model webbed dalam pembelajarannya.

\section{DAFTAR RUJUKAN}

Badan Standar Nasional Pendidikan. 2006. Standar Nasional Pendidikan. Jakarta: Badan Standar Nasional Pendidikan.

Cai, J., Lane, S., dan Jakabcsin, M. S. 1996. Assessing Students' Mathematical Comunication. Journal of Science and Mathematic, 96(5), 238-246.

Departemen Pendidikan dan Kebudayaan. 2004. Kurikulum Berbasis Kompetensi. Jakarta: Depdikbud.

Fogarty, R. 1991. How to Integrate the Curricula. Paltine: Skyligh Publishing, Inc.

Kartowagira, B. 2005. Dasar-dasar Penelitian Tindakan. Makalah disajikan dalam Penyegaran Penelitian Tindakan bagi Dosen IKIP PGRI Yogyakarta, Yogyakarta, 12 April. Pugalee, K. D. 2001. Using Communication to Develop Students' Mathematical Literacy. Mathematics Teaching in the Middle School, 6(5), 296-299.

Setiaty, R. P., Endang, B., dan Halida. 2014. Pembelajaran Terpadu Model Webbed dalam 
Memotivasi Belajar Anak Usia 4 s.d. 5 Tahun di TK Permata Bunda Pontianak Timur. Jurnal Infinity, 1(1), 20-19.

Sukayati. 2004. Pembelajaran Tematik di SD Merupakan Terapan dari Pembelajaran Terpadu. Makalah disajikan dalam Diklat Instruktur / Pengembang Matematika SD Jenjang Lanjut, Yogyakarta.

Umar, W. 2012. Membangun Kemampuan Komunikasi Matematis dalam Pembelajaran Matematika. Jurnal Infinity, 1(1), 12-19. 